\title{
ENERGY USE EFFICIENCY OF MELON (COLOCYNTHIS CITRULLUS) PRODUCTION UNDER DIFFERENT TILLAGE METHODS
}

\author{
${ }^{1}$ Ola, F.A., ${ }^{1}$ Jekayinfa, S.O., ${ }^{1}$ Akande, F.B. ${ }^{1}$ and Sanusi, B.A. ${ }^{2 *}$ \\ ${ }^{1}$ Department of Agricultural Engineering, Ladoke Akintola University of Technology, Ogbomoso \\ ${ }^{2}$ Department of Agricultural and Bio-Environmental Engineering, The Oke-Ogun Polytechnic, Saki \\ E-mail:sanusibashiradisa@gmail.com
}

\begin{abstract}
Since mechanization is inevitable and isassociated with increase in productivity, there is need to find the most appropriate tillage method in crop production that minimizes energy consumption, enhance profitability and reduce environmental damage from fossil fuel related emission. This research investigates the energy use efficiency in melon production in three tillage methods (reduced, minimum and maximum). Human power, machinery, diesel fuel, fertilizers, seed and pesticides energy inputs were used during the cultivation of melon. Input and output energy analysis method was used to quantify the input and output energy in each of the tillage methods during the production of melon. The energy indices of melon production determined are; energy efficiency, energy productivity, specific energy, net energy and energy efficiency index. The total energy required per hectare in reduced, minimum and maximum tillage were $4528.29,7191.07$ and $8325.64 \mathrm{MJ} / \mathrm{ha}$ while the output energy were found to be 8112,10404 and $10752 \mathrm{MJ} /$ ha, respectively. The energy efficiency were estimated to be $1.79,1.45$ and 1.29 while net energy were found to be $3583.71,3212.93$ and $2426.36 \mathrm{MJ} / \mathrm{ha}$ for reduced, minimum and maximum tillage methods, respectively. The result revealed that maximum tillage is better than both reduced and minimum tillage in terms of energy efficiency and net energy gain.
\end{abstract}

Keywords: Energy, Melon, Tillage, Energy Efficiency, Net Energy

DOI: $10.7176 / \mathrm{JETP} / 11-4-03$

Publication date: August $31^{\text {st }} 2021$

\section{$1.1 \quad$ Introduction}

Production of food crops such as melon (ColocynthisCitrullus) is changing from small-scale or subsistence level into commercial crop production (mechanization) which involves intensive use of more energy on the farm in form of human power, machinery, diesel fuel and other agrochemicals (Babajide and Bamgboye, 2015). Increasing requirement of higher food production has led to intensive use of agricultural and natural resources (Khoshroo, 2014). Agriculture and energy are closely related since efficient use of energy is a key factor in sustainable agricultural production. Efficient energy use in agriculture is a pathway toward decreasing environmental hazards and improving agricultural sustainability (Izadikhah and Khoshroo, 2018). In the cultivation of arable crops, soil tillage is one of the greatest energy and labour consumer. Abdussalam (2008) reported that tillage practices require $75 \%$ of the total energy consumed during crop production. Therefore, the selection of an appropriate tillage method during crop production will drastically reduce the quantity of energy that goes into production of different crops. Since mechanization is inevitable and isassociated with increase in productivity, there is need to find the most appropriate tillage method in crop production that minimizes energy consumption, enhance profitability and reduce environmental damage from fossil fuel related emission. To achieve this, the total energy input to the cropping process needstobe analyzed and estimated under different tillage methods (Nautiyal et al., 2007; Manish, 2013). Therefore, this paper studies the energy use efficiency of melon production under different tillage methods.

\section{$2 \quad$ Materials and Methods}

2.1 Experimental Procedure

Field experiment was conducted at the seed unit of the Oyo State Agricultural Development Program (OSADEP), Saki West Local Government CouncilArea of the Oyo North Senatorial District, Oyo State, Nigeria, West Africa during raining season farming from April 2018 to July, 2020. Three different tillage methods were used: reduced (tillage with hoeing), minimum (ploughing with tractor twice) and maximum (ploughing twice and harrowing once) tillage. The experimental farm consists of three treatments, three replicates which were 
arranged in a complete randomized block design and each tillage method representing a treatment. The experimental site consists of three blocks and each block consists of three plots making a total of 9 plots. The experimental farm was measured $46 \mathrm{~m}$ x $46 \mathrm{~m}$ while each block was measured $46 \mathrm{~m} \times 10 \mathrm{~m}$ and each plot $10 \mathrm{~m}$ $\mathrm{x} 10 \mathrm{~m}$ with a space of $4 \mathrm{~m}$ in between the two adjacent plots which enabled the tractor to turn conveniently without entering manually tilled plots. Melon seeds of the 1306 variety were bought from a popular agro-vet shop at Ago-Are. The seeds were directly planted in the soil using foot dibbling method asdescribed by Shafiqueet al. (2012) and Abdussalam (2015).

\subsection{Energy Analysis}

\subsubsection{Energy analysis of land preparation in tillage methods}

Land preparation in reduced tillage was carried out by using human power with the use of traditional implements such as hoes and cutlasses. For both minimum and maximum tillage, the initial land preparation was carried out with a three-bottom disc plough mounted on a New Holland (70866S) tractor makes for ploughing operations while harrowing operation was conducted using a disc harrow in maximum tillage. The operating time and the fuel consumed by the tractor per hectare during each operation was recorded and used to compute the energy input. The energy consumed during land preparation in reduced tillage and tractorized operations in both minimum and maximum tillage's were computed using equations 1 and 2 respectively as described by Bamgboye and Babajide (2015):

$$
\begin{aligned}
& E_{p}=3.6(0.075 \mathrm{NTa}) \\
& E_{l 0}=47.8 \mathrm{D}+3.6(0.075 \mathrm{NTa})
\end{aligned}
$$

1

2

Where,

$\mathrm{E}_{\mathrm{p}}=$ Human Energy consumed in land clearing in reduced tillage (MJ)

$\mathrm{E}_{\mathrm{lp}}=$ Energy consumed for land clearing in both minimum and maximum tillage (MJ)

$D=$ amount of diesel fuel consumed by operation (L)

$\mathrm{Ta}=$ useful time spent by a male worker per unit operation (min)

$N=$ number of workers involved in the operation.

\subsubsection{Energy analysis of other farming operations}

All other farming operations apart from land preparation such as planting, weeding, fertilizer application, crop protection, fruit gathering, depoding, seed extraction and seed washing in the production of melon in reduced, minimum and maximum tillage methods were carried out manually and the energy consumed in each of the operation was computed by using equation 3 as described byBamgboye and Babajide (2015):

$$
E_{p}=3.6(0.075 \mathrm{NTa})
$$

\subsubsection{Physical energy inputs}

The physical energy inputs from agrochemicals (pesticides and herbicides), fertilizer and seed energy inputs were computed by multiplying the respective energy equivalents with the quantity of the physical inputs using the expressions as described in equations 4, 5 and 6 by Haydar and Mustafa (2012).

$$
\begin{aligned}
& \text { ChemicalEnergyinput }\left(\frac{M J}{h a}\right)=\frac{\text { Quantity (liter) Wenergyequivalent }}{\text { Avvliedarea }} \\
& \text { Fertilizerenergytnput }=\frac{\text { Fertilizer }\left(\frac{\mathrm{kg}}{\mathrm{hm}}\right) \mathrm{K} \% \mathrm{NPK}}{100} \\
& \text { Seedenergy }\left(\frac{M J}{h n}\right)=\frac{\operatorname{ssed}\left(\frac{\mathrm{kg}}{\mathrm{ha}}\right) \text { MEnergyequivalent }}{\text { milivatadneran }}
\end{aligned}
$$

The energy equivalents of different energy inputs and the reference authors from literature used in the computation of the analysis of energy use efficiency for melon production under the different tillage methods are as presented in Table 1 . 


\begin{tabular}{lllll}
\multicolumn{5}{l}{ Table 1: Energy Equivalents of Inputs and Outputs in Agricultural Production } \\
\hline Input & Unit & $\begin{array}{l}\text { Energy Equivalent } \\
(\mathbf{M J} / \mathbf{k g})\end{array}$ & Reference & \\
\hline Human power & $\mathrm{h}$ & 1.97 & $\begin{array}{l}\text { Mikkola and Ahokas } \\
(2010)\end{array}$ & Mani et al., 2007 \\
Machinery & $\mathrm{Kg}$ & 69.83 & Mortezaet al., 2012 \\
Diesel fuel & $\mathrm{L}$ & 56.3 & Mortezaet al. (2012) \\
Seed & $\mathrm{Kg}$ & 1.2 &
\end{tabular}

\section{Chemical Fertilizer:}

$\begin{array}{lll}\text { Nitrogen } & \mathrm{Kg} & 47.10 \\ \text { Phosphorus } & \mathrm{Kg} & 15.80 \\ & & \\ \text { Potassium } & \mathrm{Kg} & 9.28\end{array}$

Mortezaet al. (2012)

Mortezaet al. (2012)

Mortezaet al. (2012)

Pesticides:

\begin{tabular}{llll} 
Herbicides & $\mathrm{Kg}$ & 238 & Erdalet al., 2007 \\
Fungicides & $\mathrm{kg}$ & 216 & Erdalet al., 2007 \\
Insecticides & $\mathrm{kg}$ & 101.2 & Erdalet al., 2007 \\
\hline
\end{tabular}

\subsection{Energy indices}

The energy indices in terms of energy use efficiency, energy productivity, specific energy, net energy and percentage energy index during the production of melon production were computed using equations $7,8,9,10$ and 11 as described by Asmat (2009);

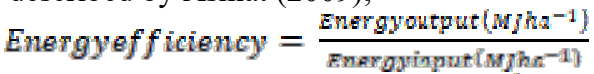

$$
\begin{aligned}
& \text { Energy Productivity }=\frac{\text { Croprield }\left(\mathrm{kgha}^{-1} \mathrm{j}\right.}{\text { Totalnergyinut }(\mathrm{Mjha}-1)} \\
& \text { Specif icEnergy }=\frac{\text { Energyinput }\left(M \mathrm{M}^{-1]}\right.}{\text { Melonyield }\left(\mathrm{MJ} h \mathrm{a}^{-1)}\right.} \\
& \text { NetEnergy = Energyoutput }- \text { Energyinput } \\
& \text { PercentageEnergylndex }=\frac{E_{p}-E_{i}}{E_{0}} X 100
\end{aligned}
$$

7

\section{$3 \quad$ Results and Discussions}

\subsection{Input and Output Energy in the Production of Melon in Tillage Methods}

The average energy input of melon production in three different tillage methods is presented in Table 2. It was observed from Table 2 that reduced tillage had the highest human energy input of $882 \mathrm{MJ} / \mathrm{ha}$, maximum tillage had a value of $693.84 \mathrm{MJ} / \mathrm{ha}$ while the least human energy input of $637 \mathrm{MJ} / \mathrm{ha}$ was expended in minimum tillage. This result was expected because all farming operations in reduced tillage were done using human power. The highest machinery input of 1110. $29 \mathrm{MJ} / \mathrm{ha}$ was expended in maximum tillage, followed by minimum tillage with value of $877.06 \mathrm{MJ} / \mathrm{ha}$ while the least machinery input of $502.78 \mathrm{MJ} / \mathrm{ha}$ was recorded in reduced tillage. Similarly, maximum tillage had the highest diesel fuel energy input of $3378 \mathrm{MJ} / \mathrm{ha}$, minimum tillage accounted for $2533.5 \mathrm{MJ} / \mathrm{ha}$ while no diesel fuel was consumed in reduced tillage treatment. The same quantity of fertilizers (1479.69 MJ/ha), seed (18.7 MJ/ha) and pesticides (1645.12 MJ/ha) wereexpended in the three tillage methods considered and energy inputs were used to avoid unbiased treatment. On the overall, maximum tillage had the highest energy input of $8325.64 \mathrm{MJ} /$ ha, followed by minimum tillage with a total energy input of $7191.07 \mathrm{MJ} /$ ha while the least energy input of $4528.29 \mathrm{MJ} / \mathrm{ha}$ was recorded in reduced tillage. Morteza et al. (212) reported the energy input values of 403.24 and $4.54 \mathrm{~kg} \mathrm{ha}^{-1}$ for total fertilizers and biocides used in the production of corn grain with total energy input of $39232.79 \mathrm{MJha}^{-1}$ for various processes. The harvested yield of melon in the three tillage methods considered were also presented in Table 2 and it was observed that maximum tillage had the highest yield of $8960 \mathrm{~kg} / \mathrm{ha}$, followed by minimum tillage with a value of $8670 \mathrm{~kg} / \mathrm{ha}$ while the least yield of $6760 \mathrm{~kg} / \mathrm{ha}$ was recorded in reduced tillage. The highest energy output of $10752 \mathrm{MJ} / \mathrm{ha}$ in maximum tillage, followed by minimum tillage with a value of $10404 \mathrm{MJ} /$ ha while the least energy output of $8112 \mathrm{MJ} /$ ha was estimated in reduced tillage. The anthropogenic energy input ratio in the production of melonis presented in Figure 1. 
Table 2: Input and Output Energy in the Production of Melon in Tillage Methods

\begin{tabular}{|c|c|c|c|c|c|c|c|c|}
\hline \multirow[t]{2}{*}{$\mathbf{S} / \mathbf{N}$} & \multirow[t]{2}{*}{ Energy input } & \multicolumn{3}{|c|}{ Quantity used in Tillage Methods (ha) } & \multirow[t]{2}{*}{$\begin{array}{c}\text { Energy } \\
\text { equivalent } \\
\text { (MJ/ha) }\end{array}$} & \multicolumn{3}{|c|}{$\begin{array}{c}\text { Total Energy Equivalent } \\
\text { (MJ/ha) }\end{array}$} \\
\hline & & Reduced & Minimum & Maximum & & Reduced & Minimum & Maximum \\
\hline 1 & Human power $(\mathrm{h})$ & 450 & 325 & 354 & 1.96 & 882 & 637 & 693.84 \\
\hline 2 & Machinery $(\mathrm{kg})$ & 7.2 & 12.56 & 15.9 & 69.83 & 502.78 & 877.06 & 1110.29 \\
\hline 3 & Diesel Fuel (1) & 00 & 45 & 60 & 56.3 & 00 & 2533.5 & 3378 \\
\hline 4 & Fertilizer $(\mathrm{kg})$ & 20.50 & 20.50 & 20.50 & 72.18 & 1479.69 & 1479.69 & 1479.69 \\
\hline 5 & Seed $(\mathrm{kg})$ & 8.5 & 8.5 & 8.5 & 1.2 & 18.7 & 18.7 & 18.7 \\
\hline 6 & Pesticide (1) & 4.85 & 4.85 & 4.85 & 339.20 & 1645.12 & 1645.12 & 1645.12 \\
\hline 7 & $\begin{array}{l}\text { Total Energy } \\
\text { input }(\mathrm{MJ} / \mathrm{ha})\end{array}$ & & & & & 4528.29 & 7191.07 & 8325.64 \\
\hline 8 & Yield $\left(\mathrm{kgha}^{-1}\right)$ & & & & & 6760 & 8670 & 8960 \\
\hline 9 & $\begin{array}{l}\text { Total Energy } \\
\text { Output (MJ/ha) }\end{array}$ & & & & & 8112 & 10404 & 10752 \\
\hline
\end{tabular}

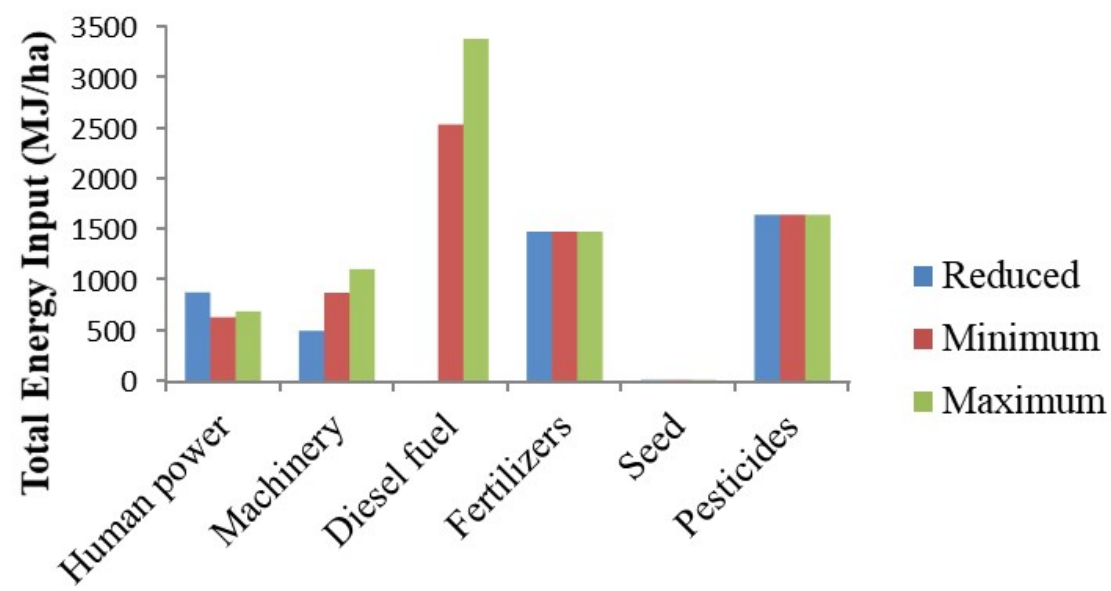

\section{Energy Inputs}

Figure 1: Anthropogenic Energy Input Ratio of Melon Production

\subsection{Energy Indices of Melon Production in Tillage Methods}

The calculated energy indices in the production of melon in three tillage methods were presented in Table 3 . It was observed from the table that the highest energy use efficiency of 1.75 was obtained in reduced tillage, minimum tillage had a value of 1.45 and the least use efficiency of 1.29 was recorded in maximum tillage. The highest energy productivity of $1.49 \mathrm{MJ} / \mathrm{kg}$ was recorded in reduced tillage, followed by minimum tillage with a value of $1.20 \mathrm{MJ} / \mathrm{kg}$ while the least energy productivity of $1.08 \mathrm{MJ} / \mathrm{kg}$ was noticed in maximum tillage. Similarly, maximum tillage had the highest specific energy of $0.93 \mathrm{MJ} / \mathrm{ha}$, followed by minimum tillage with a value $0.83 \mathrm{MJ} / \mathrm{ha}$ and the least specific energy value of $0.67 \mathrm{MJ} / \mathrm{ha}$ was calculated in reduced tillage. The highest net energy value of 3583.71 was estimated in reduced tillage, followed by minimum tillage with net energy value of $3212.93 \mathrm{MJ} / \mathrm{ha}$ whiles the least net energy value of $2426.36 \mathrm{MJ} /$ ha was estimated in maximum tillage. The highest energy efficiency index of 0.44 was calculated for reduced tillage, minimum tillage had a value of 0.31 while the least energy efficiency index of 0.23 was calculated for maximum tillage. 
Table 3: Energy Indices in the Production of Melon in Tillage Methods (Results)

\begin{tabular}{lllll}
\hline S/N & Energy Indices & \multicolumn{3}{c}{ Tillage Methods } \\
\hline & & Reduced & Minimum & Maximum \\
1 & Total Energy Input (MJ/ha) & 4528.29 & 7191.07 & 8325.64 \\
2 & ${\text { Yield }\left(\mathrm{kgha}^{-1}\right)}$ & 6760 & 8670 & 8960 \\
3 & Total Energy output (MJ/ha) & 8112 & 10404 & 10752 \\
4 & Energy Efficiency & 1.79 & 1.45 & 1.29 \\
5 & Energy Productivity $\left(\mathrm{MJkg}^{-1}\right)$ & 1.49 & 1.20 & 1.08 \\
6 & Specific Energy(MJha & \\
7 & Net Energy MJha & & 0.93 \\
8 & Energy Efficiency Index (\%) & 0.67 & 3212.93 & 2426.36 \\
\hline
\end{tabular}

\subsection{Percentage Composition of Energy Input}

The percentage composition of energy input from human power, machinery, diesel fuel, fertilizers, seed and pesticides is depicted in Figure 2. It was observed from Figure 2(a) that in reduced tillage, pesticides had the highest percentage value of $36.33 \%$ of the total energy input,

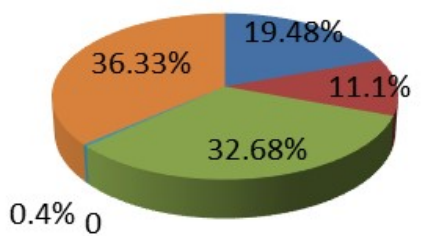

(a) : Reduced

- Human power
- Machinery
Diesel fuel
- Fertilizers
Seed
- Pesticides

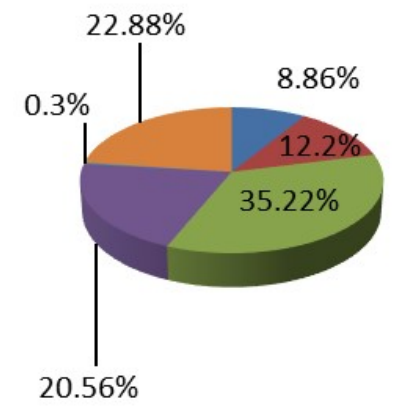

(b) : Minimum

- Human power
- Machinery
- Diesel fuel
- Fertilizers
Seed
- Pesticides

Pesticides

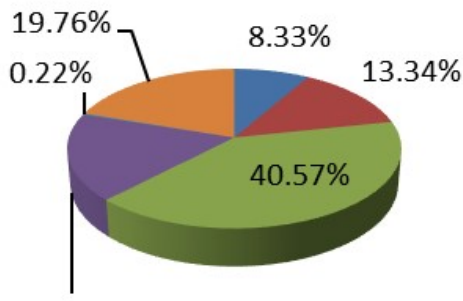

$17.77 \%$

Human power

Machinery

Diesel fuel

Fertillizers

Seed

Pesticides

(c) Maximum

Figure 2: Percentage Composition of Energy Inputs in Tillage Methods; (a) Reduced, (b) Minimum and (c) Maximum Tillages

fertilizer, human power; machinery had the values of 32.68, 19.48 and $11.10 \%$, respectively, while the least percentage energy input of $0.4 \%$ was recorded in seed energy input. Similarly, Figure 2(b) shows that in minimum tillage, diesel fuel had the highest energy input of $35.22 \%$, pesticides, fertilizers, machinery and human power recorded the percentage values of $22.88,20.55,12.20$ and $8.86 \%$, respectively, while the least energy input of $0.3 \%$ was observed in seed energy input. Figure 2(c) also shows the percentage composition of energy input in maximum tillage and it was observed that the highest percentage energy input of $40.57 \%$ was recorded in diesel fuel, pesticides, fertilizers, machinery and human power recorded the percentage values of $19.76,17.77,13.34$ and $8.33 \%$, respectively, while seed energy input had the least percentage value of $0.22 \%$. Oladimeji et al. (2016) report a total energy input of $4329.7 \mathrm{MJ} / \mathrm{ha}$ for semi mechanized farm and $2687 \mathrm{MJ} / \mathrm{ha}$ for traditional farm. Total Energy Equivalent (TEE) of $45.5 \mathrm{MJ}$ of labour, $451.4 \mathrm{MJ}$ of machinery, $600 \mathrm{MJ}$ of herbicide, 255 MJ of FYM, 661.4 MJ of nitrogen, 119.3 MJ of phosphate, $67 \mathrm{MJ}$ of potassium, 1221.7 MJ of diesel and 908.4 MJ of seedling materials were reported for semi mechanized farm while Total Energy Equivalent (TEE) of 97.8 MJ of labour, 216 MJ of herbicide, 753.3 MJ of FYM, and equal amount of nitrogen, phosphate and potassium were used in traditional farms. 


\section{Conclusions}

In this study, the energy use efficiency of melon production under different tillage methods has been investigated and the following results were obtained:

1. Maximum tillage consumed the highest energy input with a total of $8325.64 \mathrm{MJ} / \mathrm{ha}$, followed by minimum tillage with a value of $7191.07 \mathrm{MJ} / \mathrm{ha}$ while reduced tillage had the least total energy value of 4528.29 MJ/ha.

2. Diesel fuel is the major energy input in both minimum $(35.22 \%)$ and maximum $(40.57 \%)$ tillage while pesticide $(36.33 \%)$ is the most energy input in reduced tillage.

\section{References}

Abdussalam, O.Y. (2015). Modelling of Energy Requirement Demand for Tillage Operations in Maize Production. An Unpublished ph.D Thesis submitted to the Department of Agricultural Engineering Ahmadu Bello University, Zaria, Nigeria.

Bamgboye, A.I. and S.K. Babajide, (2015). Energy Input in the Production of Cassava. Journal of Energy and Environmental Research, 5 (1): 42-48. DOI:10.5539/eer.v5n1p42

Erdal, H., K. Esengun and G. Erdal (2009). The Functional Relationship between Energy Inputs and Fruit Yield: A Case Study of Stake Tomato in Turkey. Journal of Sustainable $\quad$ Agriculture, 33: 835-847.

Khoshroo, A. (2014). Energy use Pattern and Greenhouse Gas Emission of Wheat Production: A Case Study in Iran. Agricultural Communications, 2: 9-14.

Khoshroo, A. and M. Izadikhah (2018). Improving Efficiency of Farming Products through Benchmarking and Data Envelopment Analysis. Int. J. Manag. Decis. Making (in press).

Mani, I., P. Kumar., J. S. Panwar. and K. Kant (2007). Variation in Energy Consumption in Production of Wheat-Maize with Varying Altitudes in Hilly Regions of Himachal Pradesh. India Energy, 32: 2336-2339.

Mikkola, J. H. and J. Ahokas (2010). Indirect Energy Input of Agricultural Machinery in Bio- Energy Production. Renewable Energy, 35: 23-8.

Morteza, T., G. M. Hassan, and M. Y. Nasim (2012). Energy Input-Output Modeling and Economical Analyze for Corn Grain Production in Iran. Journal of Elixir Agriculture, $\quad$ 52:11500-11505

Nautiyal. S, H., K. S. Kaechele., R. K. Rao and K. G. Saxena (2007). Energy and Economic Analysis of Traditional Versus Introduced Crops Cultivation in the Mountains of the Indian Himalayas. AgroEcosystems, 4:355-366.

Oladimeji., Y. U., Abdulsalam, Z., Lawal, A. F, Suleiman, R. and Olarewaju, T. O. (2016)energy use and economic analysis of melon (colocynthis citrullus 1.) production technologies in kwara state Nigeria. Nigerian Journal of Agriculture, Food and Environment. 12(3):162-168

Shafique, Q. M., S. M. Muhammad., Q M. Abdul and A. Nadeem (2012). Evaluation of Inputs and Outputs Energy for Maize Grain Yield. Sarhad Journal of Agriculture, 28(3): 223-226 